Check for updates

Cite this: RSC Adv., 2017, 7, 52423

\section{Effect of gellan and calcium chloride on properties of surimi gel with low and high setting phenomena}

\author{
Tanyamon Petcharat and Soottawat Benjakul (iD*
}

The properties of bigeye snapper surimi gel as affected by gellan (GL) at different levels (2-6\% based on solid content of surimi) in combination with calcium chloride $\left(\mathrm{CaCl}_{2}\right)$ at various concentrations (25-75 mmol kg-1) were examined. The breaking force, hardness and whiteness of surimi gel increased but the expressible moisture content decreased as both levels of $\mathrm{GL}$ and $\mathrm{CaCl}_{2}$ increased $(p<0.05)$. Electrophoretic studies showed that $\mathrm{GL}$ and $\mathrm{CaCl}_{2}$ at all levels had no effect on polymerization of myosin heavy chain $(\mathrm{MHC})$. The highest overall likeness score was found in the gel containing $4 \% \mathrm{GL}$ and $75 \mathrm{mmol} \mathrm{CaCl} 2$ per $\mathrm{kg}$ ( $p<0.05$ ). The effects of $\mathrm{GL}$ and $\mathrm{CaCl}_{2}$ in the absence of endogenous transglutaminase (TGase) on surimi gel properties were also evaluated. Both $\mathrm{GL}$ and $\mathrm{CaCl}_{2}$ increased the breaking force, water holding capacity and whiteness of TGase free surimi gels $(p<0.05)$. Based on rheological study, $\mathrm{GL}$ and $\mathrm{CaCl}_{2}$ could enhance the interconnection between chains during heating as indicated by the higher $G^{\prime}$. Different $G^{\prime}$ curves were obtained between surimi in the presence and absence of TGase. The protein pattern revealed an important role of TGase in the MHC cross-linking of surimi gel. Microstructure studies demonstrated that a finer and denser network was observed in the surimi gel containing $4 \% \mathrm{GL}$ and $75 \mathrm{mmol} \mathrm{CaCl}_{2}$ per $\mathrm{kg}$ in the presence of TGase, whereas a coarser network was obtained in gels free of TGase. Therefore, $\mathrm{GL}$ and $\mathrm{CaCl}_{2}$ at an appropriate level could be used to improve the gel properties of surimi with either low or high setting phenomenon mediated by endogenous TGase.
Received 2nd October 2017 Accepted 6th November 2017 DOI: $10.1039 / c 7 r a 10869 a$ rsc.li/rsc-advances phenolic compounds ${ }^{8}$ have been added to strengthen the gel network of surimi. Moreover, some hydrocolloids such as curdlan, pullulan, carrageenan, pectin, etc. have been employed to strengthen surimi gels. ${ }^{9-12}$

Gellan is the latest biopolymer available on the market and it has been used by the food industry as gelling agent. ${ }^{13}$ Gellan is the anionic polysaccharide produced by the microorganism, Pseudomonas elodea. It consists of repeat units of $\beta$-D-glucose (DGlc), $\beta$-D-glucuronic acid (D-GlcA) and $\alpha$-L-rhamnose (L-Rha) in a molar ratio of $2: 1: 1{ }^{14}$ During gelation, gellan is converted from a disordered i.e. random coil conformation to ordered form. When hot solutions are cooled, double helix structures are formed, primarily through intramolecular interactions. ${ }^{15} \mathrm{In}$ the presence of gel promoting cations, especially divalent cation $\left(\mathrm{Ca}^{2+}\right)$, the double helices form cation-mediated junction zones, in which the strong gel networks can be developed. ${ }^{16}$ Due to the gelling ability of gellan, it has been used in protein-based gels including fish gelatin and myofibrillar proteins. The addition of gellan at $2.5 \%$ in combination with $\mathrm{CaCl}_{2}$ up to $6 \mathrm{mmol} \mathrm{kg}^{-1}$ into fish gelatin had no negative effect on sensory property of mixed gels but could increase gel strength and gelling points. ${ }^{17}$ In addition, gellan was used to improve quality of reduced-fat frankfurters. Konjac (1\% and $2 \%)$ in combination with gellan $(0.25 \%$ and $0.5 \%)$ were incorporated into reduced fat $(18 \%)$ frankfurters, yielding the finished product with acceptability. ${ }^{18}$ 
Recently, Petcharat and Benjakul (2017) has reported that gellan, prepared as suspension, at 6\% could improve gel strength of bigeye snapper surimi gel with the highest acceptability as indicated by the increased breaking force and the highest overall likeness score. ${ }^{\mathbf{1 9}}$

Setting phenomenon has been known to enhance gel strength of surimi. TGase play an important role in formation of $\varepsilon$ - $(\gamma$-glutamyl $)$ lysine linkage during setting. ${ }^{7}$ Nevertheless, surimi from some fish species has poor setting, due to the lower levels of TGase. ${ }^{1}$ To tackle such a problem, microbial TGase (MTGase) has been used. ${ }^{20}$ Incorporation of divalent cation into surimi in the presence of gellan could be a promising means to improve the gelling property of surimi. Gellan can gel as induced by $\mathrm{Ca}^{2+} .{ }^{21}$ Simultaneously both gellan gel formed and $\mathrm{Ca}^{2+}$ are able to strengthen the surimi network. $\mathrm{Ca}^{2+}$ can induce protein cross-linking mediated by TGase and via $\mathrm{Ca}^{2+}$ bridge. ${ }^{22}$ The use of gellan, particularly in the presence of $\mathrm{Ca}^{2+}$, could be a promising means to improve the property of surimi gel, especially those with poor gelling property associated with low setting phenomenon. Therefore, the present study aimed to investigate the effect of gellan in combination with calcium chloride on the gel properties of surimi gel from bigeye snapper in the absence and presence of TGase.

\section{Materials and methods}

\subsection{Materials}

Food-grade low acyl gellan was purchased from CP Kelco (Atlanta, GA, USA). Frozen surimi from bigeye snapper (Priacanthus macranthus), Grade A, was obtained from Man A Frozen Foods Co., Ltd. (Songkhla, Thailand) and kept at $-20{ }^{\circ} \mathrm{C}$ until use but not longer than 2 months. Surimi had a moisture content of $75 \%(w / w)$ as determined by an oven method. ${ }^{23}$

\subsection{Preparation of gellan (GL) suspension}

GL (1, 2 and $3 \mathrm{~g})$ was dispersed in distilled water at a GL/water ratio of $1: 15(\mathrm{w} / \mathrm{v})$. Ultrasound was applied using an ultrasonic processor (Sonics, Model VC750, Sonica \& Materials, Inc., Newtown, CT, USA) at an amplitude of $40 \%$ for $4 \mathrm{~min}$ with a constant frequency of $20 \mathrm{kHz} \pm 50 \mathrm{~Hz}$ and high intensity power of $750 \mathrm{~W}$.

\subsection{Study on impact of GL and $\mathrm{CaCl}_{2}$ at different levels on properties of surimi gel}

Frozen surimi (200 g) was partially thawed at $4{ }^{\circ} \mathrm{C}$ for $2-3 \mathrm{~h}$ until the core temperature reached $0-2{ }^{\circ} \mathrm{C}$. The surimi was chopped into small pieces and mixed with $2.5 \%$ salt in a mixer (Panasonic, Model MK-5087M, Selangor, Malaysia) for $2 \mathrm{~min}$. During chopping, the temperature was maintained below $10{ }^{\circ} \mathrm{C}$. The paste was added with gellan suspension to obtain the final GL levels of $0,2,4$ and $6 \%$ (based on surimi solid content). The moisture content of all surimi paste was adjusted to $80 \%$ with cold distilled water. Calcium chloride $\left(\mathrm{CaCl}_{2}\right)$ was added to the paste to obtain the final different concentrations $(0,25,50$ and $75 \mathrm{mmol} \mathrm{kg}^{-1}$ paste). Subsequently, the mixture was chopped for another $3 \mathrm{~min}$ and the paste was stuffed into a polyvinylidene chloride casing with a diameter of $2.5 \mathrm{~cm}$. The casing containing paste was sealed tightly and subjected to the incubation at $40{ }^{\circ} \mathrm{C}$ for $30 \mathrm{~min}$, followed by heating at $90{ }^{\circ} \mathrm{C}$ for $20 \mathrm{~min}$. Thereafter, all gels were cooled in iced water for $30 \mathrm{~min}$ and stored at $4{ }^{\circ} \mathrm{C}$ for $24 \mathrm{~h}$ prior to analyses. Gel samples, added with the same level of $\mathrm{CaCl}_{2}$, were also prepared and referred to as the controls.

\subsection{Analyses}

2.4.1 Breaking force and deformation. Breaking force (gel strength) and deformation (deformability) of surimi gels were determined using a texture analyzer (Model TA-XT2, Stable MicroSystems, Surrey, UK) as described by Benjakul et al. (2001). ${ }^{24}$ Cylindrical gel samples $(2.5 \mathrm{~cm}$ in height $)$ were prepared and equilibrated at room temperature $\left(28-30{ }^{\circ} \mathrm{C}\right)$ for $30 \mathrm{~min}$ before analyses. A spherical plunger (diameter $5 \mathrm{~mm}$ ) was pressed into the cut surface of a gel sample perpendicularly at a constant depression speed $\left(60 \mathrm{~mm} \mathrm{~min}^{-1}\right)$. The force to puncture into the gel (breaking force) and the distance at which the plunger punctured into the gel (deformation) were recorded.

2.4.2 Texture profile analysis. Gel samples were subjected to texture profile analysis (TPA) following the method of Buamard and Benjakul (2015). ${ }^{25}$ A texture analyzer (Model TA-XT2, Stable MicroSystems, Surrey, UK) with a load cell of $50 \mathrm{~kg}$ and a cylindrical aluminium probe (diameter $50 \mathrm{~mm}$ ) was used. The samples were placed on the instrument's base and the tests were run with two compression cycles. TPA textural parameters were measured with the following testing conditions: crosshead speed of $0.5 \mathrm{~mm} \mathrm{~s}^{-1}, 50 \%$ compression of the original sample height, and a time interval between the first and second compression of 10 s. Hardness, cohesiveness, springiness, chewiness and gumminess were calculated from the force-time curves.

2.4.3 Expressible moisture content. Gel samples were measured for expressible moisture content according to the method of Chanarat et al. (2012). ${ }^{20}$ Cylindrical gel samples $(2.5 \mathrm{~cm}$ diameter and $5 \mathrm{~mm}$ height) were weighed accurately $(X)$. Three pieces of Whatman filter paper No. 1 (Whatman International Ltd., Maidstone, UK) were placed at the bottom of sample, while two pieces were covered on the top. A standard weight of $5 \mathrm{~kg}$ was placed on the top of the sample for $2 \mathrm{~min}$. After being removed from the papers, the samples were weighed again $(Y)$. Expressible moisture content was calculated as percentage of sample weight by the following equation:

$$
\text { Expressible moisture }(\%)=[(X-Y) / X] \times 100
$$

2.4.4 Whiteness. Whiteness in all gel samples was measured using a colorimeter (HunterLab, Colorflex, Hunter Associates Laboratory, VA, USA). $L^{*}, a^{*}$ and $b^{*}$ values indicating lightness/brightness, redness/greenness and yellowness/ blueness, respectively, were measured and recorded. Whiteness was then calculated using the following equation: ${ }^{26}$

$$
\text { Whiteness }=100-\left[\left(100-L^{*}\right)^{2}+a^{*^{2}}+b^{* 2}\right]^{1 / 2}
$$


2.4.5 SDS-polyacrylamide gel electrophoresis (SDS-PAGE). Protein patterns of surimi paste and gels were analyzed by SDSPAGE under the reducing condition according to the method of Laemmli (1970). ${ }^{27}$ To solubilize the proteins in gel samples, finely chopped samples $(3 \mathrm{~g})$ were added with $27 \mathrm{~mL}$ of heated SDS solution $\left(85^{\circ} \mathrm{C}\right)$. The mixture was subsequently homogenized at a speed of $11000 \mathrm{rpm}$ for 2 min using a homogenizer (IKA, Labortechnik homogenizer Selangor, Malaysia). To dissolve total proteins, the homogenate was incubated at $85{ }^{\circ} \mathrm{C}$ for $1 \mathrm{~h}$. The mixture was centrifuged at $3500 \times g$ for $20 \mathrm{~min}$ to remove the undissolved debris. Protein concentration of the supernatant was determined by the Biuret method ${ }^{28}$ using bovine serum albumin as standard. The samples ( $15 \mu \mathrm{g}$ protein) were loaded onto the SDS-PAGE gel, which consisted of $10 \%$ running gel and $4 \%$ stacking gel. After separation, the proteins were stained with $0.02 \%(\mathrm{w} / \mathrm{v})$ coomassie brilliant blue R-250 in $50 \%(\mathrm{v} / \mathrm{v})$ methanol and $7.5 \%(\mathrm{v} / \mathrm{v})$ acetic acid and destained with $50 \%$ methanol and $7.5 \%(\mathrm{v} / \mathrm{v})$ acetic acid, followed by $5 \%$ methanol (v/v) and 7.5\% (v/v) acetic acid.

2.4.6 Sensory property. Surimi gels added with GL at $0,2,4$ and $6 \%$ in the absence or presence of $\mathrm{CaCl}_{2}$ at a level of $75 \mathrm{mmol} \mathrm{kg}^{-1}$ were examined. Gel samples were cut into a bitesize ( $1 \mathrm{~cm}$ thickness and $2.5 \mathrm{~cm}$ diameter), equilibrated at room temperature $\left(28-30{ }^{\circ} \mathrm{C}\right.$ ) for $30 \mathrm{~min}$ and coded with 3-digit random numbers. Samples were kept in plastic cup with the cover before the sensory evaluation. Fifty non-trained panelists (aged between 20 and 45), who were the students and staffs at Department of Food Technology and were accustomed with surimi products, were asked to evaluate for appearance, color, odor, firmness, springiness, taste and overall liking of gel samples using 9-point hedonic scale. ${ }^{29}$ Gel samples were served at room temperature under the fluorescent daylight-type illumination. Between samples, panelists were asked to rinse their mouth with drinking water at room temperature.

\subsection{Study on the effect of $\mathrm{GL}$ and $\mathrm{CaCl}_{2}$ at the selected concentration on properties of surimi without and with TGase}

To prepare surimi without endogenous TGase, $\mathrm{NH}_{4} \mathrm{Cl}$ at a level of $1 \mathrm{~mol} \mathrm{~kg}{ }^{-1}$ was added into surimi paste. ${ }^{30}$ Surimi paste (without $\mathrm{NH}_{4} \mathrm{Cl}$ ) was also used to represent that containing TGase. For each surimi (without and with TGase), different samples were prepared. Those included (1) surimi gel (without GL and $\mathrm{CaCl}_{2}$ ), (2) gel added with $75 \mathrm{mmol} \mathrm{CaCl}_{2} \mathrm{~kg}^{-1}$, (3) gel added with $4 \%$ GL and (4) gel added with $4 \%$ GL in combination with $75 \mathrm{mmol} \mathrm{CaCl}_{2} \mathrm{~kg}^{-1}$. The preparation of surimi gels was performed as previously described.

Gels were subjected to analyses of breaking force, deformation, expressible moisture content, whiteness and protein pattern as described previously. Additional analyses including dynamic rheology and microstructure were also performed.

2.5.1 Dynamic rheology. Surimi pastes were prepared as previously described and then subjected to dynamic rheological measurements as per the method of Singh and Benjakul (2017). ${ }^{31}$ A controlled stress rheometer (HAAKE RheoStress1, ThermoFisher Scientific, Karlsruhe, Germany) with $35 \mathrm{~mm}$ parallel plate geometry was used for monitoring the changes in storage or elastic modulus $\left(G^{\prime}\right)$. The measurement was performed at a constant frequency of $1 \mathrm{~Hz}$ and an amplitude strain of $1 \%$. This condition yielded a linear response in the viscoelastic region. The temperature sweep was recorded during heating from 10 to $90{ }^{\circ} \mathrm{C}$, where the heating rate of $1{ }^{\circ} \mathrm{C} \mathrm{min}{ }^{-1}$ was used. Silicon oil was applied to cover the samples in order to minimize water evaporation of surimi pastes during measurement.

2.5.2 Microstructure. Microstructure of gel samples were examined using a scanning electron microscope (SEM). The samples with a thickness of $2-3 \mathrm{~mm}$ were fixed with $2.5 \%(\mathrm{v} / \mathrm{v})$ glutaraldehyde in $0.2 \mathrm{M}$ phosphate buffer $(\mathrm{pH}$ 7.2) for $3 \mathrm{~h}$ at room temperature, followed by rinsing with distilled water. Fixed specimens were dehydrated in ethanol with serial concentrations of 25, 50, 70, 80, 90, and 100\%. Samples were critical point dried using $\mathrm{CO}_{2}$ as transition fluid. The prepared samples were mounted on a bronze stub and sputter-coated with gold. The specimens were visualized using SEM (Quanta 400, FEI, Eindhoven, the Netherlands).

\subsection{Statistical analysis}

All experiments were run in triplicate. Data were subjected to analysis of variance (ANOVA). Comparison of means was carried out by the Duncan's multiple range test. ${ }^{32}$ Statistical analysis was performed using SPSS for Windows (SPSS Inc., Chicago, IL, USA). Data with $p<0.05$ were considered to be statistically significant.

\section{Results and discussion}

\subsection{Textural and physical properties of surimi gel as affected} by gellan and $\mathrm{CaCl}_{2}$ at various concentrations

3.1.1 Breaking force and deformation. Breaking force is one of the most important properties of surimi gels and the application of gel is generally governed by this value. When comparing the breaking force of all samples, the control gel (without $\mathrm{GL}$ and $\mathrm{CaCl}_{2}$ ) had the lowest breaking force (317 g) ( $p$ $<0.05)$. In the absence of $\mathrm{CaCl}_{2}$, breaking force of resulting gels increased as the level of GL increased $(p<0.05)$ (Fig. 1A). Gellan plausibly acted as an active filler, which was able to interact with surimi proteins to form the stronger network as evidenced by the increased breaking force. Protein-hydrocolloids interactions mainly occur via electrostatic interaction between opposite charges between proteins and hydrocolloids. ${ }^{33}$ Carboxyl group of GL might undergo ionic interaction with the positively charged residues of myofibrillar proteins, thereby leading to the strengthened gel network. Without GL added, breaking force of surimi gels increased when the concentration of $\mathrm{CaCl}_{2}$ increased $(p<0.05) \cdot \mathrm{Ca}^{2+}$ could form salt linkages between negatively charge localized on two adjacent proteins. ${ }^{22}$ In addition, $\mathrm{Ca}^{2+}$ could activate endogenous transglutaminase (TGase) in surimi. TGase can catalyze the acyl transfer reaction between $\gamma$-carboxyamide groups of glutamine and $\varepsilon$-amino groups of lysine, resulting in the formation of $\varepsilon$-( $\gamma$-glutamyl) lysine cross-linkings and stronger gels. ${ }^{30}$ Similar trend was observed for all surimi gel added with GL at all levels, in which 


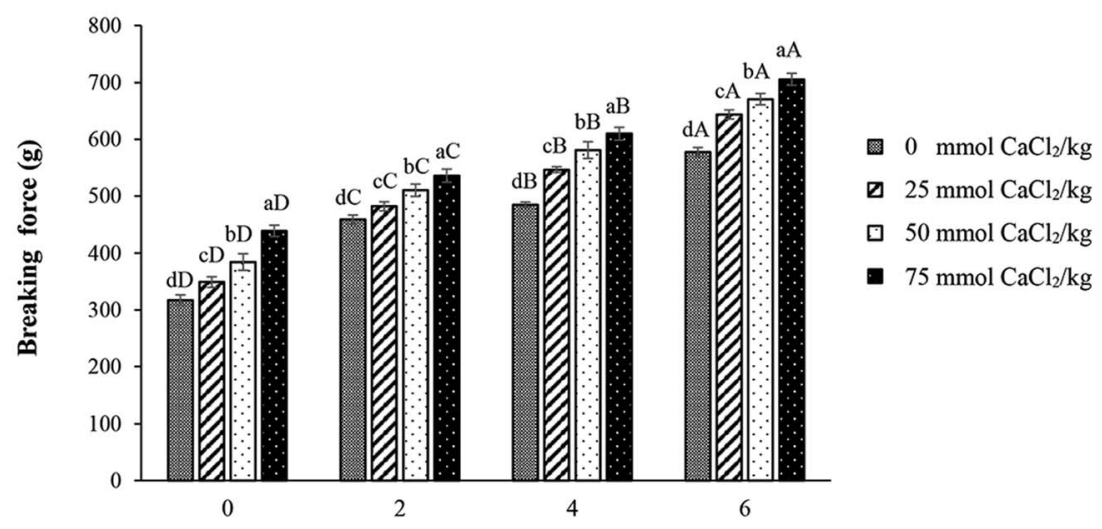

B

Gellan levels (\%, based on surimi solid content)

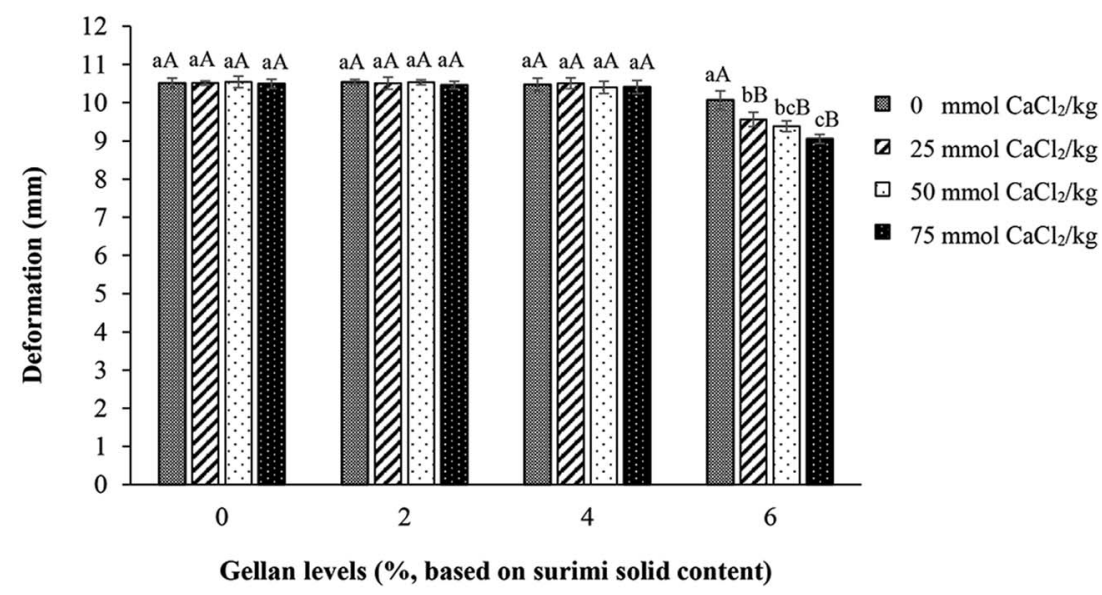

Fig. 1 Breaking force (A) and deformation (B) of gels from bigeye snapper surimi as affected by $\mathrm{GL}$ and $\mathrm{CaCl}_{2}$ at different levels. Bars represent the standard deviation $(n=3)$. Lowercase or uppercase letters on the bar within the same $\mathrm{GL}$ or $\mathrm{CaCl}_{2}$ levels, respectively, indicate significant differences $(p<0.05)$.

the higher breaking force was obtained with increasing $\mathrm{CaCl}_{2}$ levels $(p<0.05)$. However, at higher level of GL, breaking force of resulting gel was higher $(p<0.05)$. Among all gel samples, surimi gel containing $6 \%$ GL and $75 \mathrm{mmol} \mathrm{CaCl}_{2} \mathrm{~kg}^{-1}$ had the highest breaking force $(706 \mathrm{~g})(p<0.05)$, in which breaking force was increased by $122 \%$, compared to that of control (without GL and $\mathrm{CaCl}_{2}$ ). The result indicated that the concentration of $\mathrm{CaCl}_{2}$ had the profound impact on gel property of surimi gel containing GL. Theoretically, gelation of gellan was induced by cations. Calcium ions promote the aggregation process by sitebinding between pairs of carboxyl groups on neighboring helices to give structures analogous to the "egg box" junctions as proposed for calcium induced gelation of alginate or pectin. ${ }^{34}$ It was noted that the addition of GL in combination with $\mathrm{CaCl}_{2}$ had no effect on deformation of resulting gel $(p>0.05)$, except for gel containing $6 \% \mathrm{GL}$. The addition of $\mathrm{CaCl}_{2}$ up to $75 \mathrm{mmol} \mathrm{kg}{ }^{-1}$ resulted in the continuous decrease in deformation ( $p<0.05)$ (Fig. 1B). Thus, deformation of resulting gel was not much affected by incorporation of GL and $\mathrm{CaCl}_{2}$ when the appropriate levels of both additives were used. Excessive strong bonding or interaction in network could lead to the loss in flexibility of gel, as indicated by the decreased deformation. Some hydrocolloids have been employed in surimi in conjunction with salts. Eom et al. (2013) reported that the addition of $\kappa$-carrageenan into Alaska pollock surimi increased breaking force and gel strength of surimi gels. ${ }^{35}$ Gels with $1 \%$ k-carrageenan and $\mathrm{KCl}$ had the highest breaking force and gel strength. Furthermore, Hunt and Park (2013) also studied the impact of refined iota- and kappa-carrageenan $(0.25-1.0 \%)$ in Alaska pollock fish proteins as affected by various salts ( $\mathrm{NaCl}, \mathrm{KCl}$ or $\mathrm{CaCl}_{2}$, at $2 \%$ ). $\mathrm{KCl}$ and $\mathrm{NaCl}$ in combination with kappa- and iota-carrageenan could increase gel strength and water retention ability of fish protein gel. ${ }^{11}$

3.1.2 Textural properties. TPA parameters of surimi gels incorporated with GL at various levels in the absence and presence of $\mathrm{CaCl}_{2}$ at different concentrations are depicted in Table 1. Hardness of surimi gel generally increased with increasing GL content $(p<0.05)$, regardless of $\mathrm{CaCl}_{2}$ levels. At the same level of GL, hardness of resulting gels increased as the concentration of $\mathrm{CaCl}_{2}$ increased $(p<0.05)$. The highest hardness $(68.16 \mathrm{~N})$ was found in gel containing $6 \% \mathrm{GL}$ and $75 \mathrm{mmol}$ $\mathrm{CaCl}_{2} \mathrm{~kg}^{-1}(p<0.05)$. This was related to the highest breaking 
Table 1 Texture profile analysis (TPA) of bigeye snapper surimi gel as affected by the addition of GL and $\mathrm{CaCl}_{2}$ at different levels ${ }^{b}$

\begin{tabular}{|c|c|c|c|c|c|c|}
\hline $\operatorname{Gellan}^{a}(\%)$ & $\mathrm{CaCl}_{2}\left(\mathrm{mmol} \mathrm{kg}{ }^{-1}\right)$ & Hardness (N) & Springiness $(\mathrm{cm})$ & Cohesiveness & Gumminess (N) & Chewiness $(\mathrm{N} \times \mathrm{cm})$ \\
\hline 0 & - & $39.69 \pm 0.63^{\mathrm{dD}}$ & $0.92 \pm 0.01^{\mathrm{aA}}$ & $0.78 \pm 0.00^{\mathrm{aA}}$ & $31.00 \pm 0.47^{\mathrm{dD}}$ & $28.49 \pm 0.69^{\mathrm{dD}}$ \\
\hline & 25 & $40.74 \pm 0.52^{\mathrm{cD}}$ & $0.91 \pm 0.02^{\mathrm{aA}}$ & $0.78 \pm 0.01^{\mathrm{aA}}$ & $31.64 \pm 0.35^{\mathrm{cD}}$ & $28.88 \pm 0.79^{\mathrm{cD}}$ \\
\hline & 75 & $43.01 \pm 0.10^{\mathrm{aD}}$ & $0.92 \pm 0.01^{\mathrm{aA}}$ & $0.77 \pm 0.01^{\mathrm{aA}}$ & $33.28 \pm 0.34^{\mathrm{aD}}$ & $30.64 \pm 0.38^{\mathrm{aD}}$ \\
\hline \multirow[t]{2}{*}{2} & - & $57.39 \pm 0.32^{\mathrm{dC}}$ & $0.92 \pm 0.00^{\mathrm{aA}}$ & $0.75 \pm 0.01^{\mathrm{aB}}$ & $42.99 \pm 0.24^{\mathrm{dC}}$ & $39.75 \pm 0.34^{\mathrm{dC}}$ \\
\hline & 25 & $58.29 \pm 0.46^{\mathrm{cC}}$ & $0.91 \pm 0.01^{\mathrm{aA}}$ & $0.74 \pm 0.01^{\mathrm{aB}}$ & $43.24 \pm 0.27^{\mathrm{cC}}$ & $39.95 \pm 0.51^{\mathrm{cC}}$ \\
\hline \multirow[t]{4}{*}{4} & - & $59.11 \pm 0.22^{\mathrm{dB}}$ & $0.91 \pm 0.01^{\mathrm{aA}}$ & $0.75 \pm 0.01^{\mathrm{aB}}$ & $44.22 \pm 0.74^{\mathrm{dB}}$ & $40.29 \pm 0.55^{\mathrm{dB}}$ \\
\hline & 25 & $62.61 \pm 0.21^{\mathrm{cB}}$ & $0.92 \pm 0.00^{\mathrm{aA}}$ & $0.75 \pm 0.03^{\mathrm{aB}}$ & $47.26 \pm 0.89^{\mathrm{cB}}$ & $43.65 \pm 0.79^{\mathrm{cB}}$ \\
\hline & 50 & $63.74 \pm 0.04^{\mathrm{bB}}$ & $0.92 \pm 0.01^{\mathrm{aA}}$ & $0.75 \pm 0.02^{\mathrm{aB}}$ & $47.56 \pm 0.29^{\mathrm{bB}}$ & $43.72 \pm 0.46^{\mathrm{bB}}$ \\
\hline & 75 & $65.38 \pm 0.15^{\mathrm{aB}}$ & $0.92 \pm 0.01^{\mathrm{aA}}$ & $0.75 \pm 0.01^{\mathrm{aB}}$ & $49.15 \pm 0.47^{\mathrm{aB}}$ & $45.15 \pm 0.83^{\mathrm{aB}}$ \\
\hline \multirow[t]{2}{*}{6} & - & $63.00 \pm 0.16^{\mathrm{dA}}$ & $0.92 \pm 0.01^{\mathrm{aA}}$ & $0.75 \pm 0.01^{\mathrm{aB}}$ & $46.99 \pm 0.43^{\mathrm{dA}}$ & $42.12 \pm 0.59^{\mathrm{dA}}$ \\
\hline & 25 & $64.28 \pm 0.22^{\mathrm{cA}}$ & $0.90 \pm 0.01^{\mathrm{bB}}$ & $0.73 \pm 0.01^{\mathrm{bC}}$ & $47.06 \pm 0.92^{\mathrm{cA}}$ & $43.78 \pm 0.34^{\mathrm{cA}}$ \\
\hline
\end{tabular}

${ }^{a}$ Based on surimi solid content. ${ }^{b}$ Values are presented as mean $\pm \mathrm{SD}(n=3)$. Different lowercase superscripts in the same column within the same GL level indicate significant differences $(p<0.05)$. Different uppercase superscripts in the same column within the same CaCl ${ }_{2}$ indicate significant differences $(p<0.05)$.

force (Fig. 1A). These results revealed that GL showed gel strengthening effect on surimi gel from bigeye snapper by acting as filler or binder in surimi gel network. $\mathrm{Ca}^{2+}$ is able to link to the zones, thus increasing the network structure via the formation of bridges between both biopolymers, resulting in the increases in both breaking force and hardness. The increases in hardness of surimi gel without and with GL were observed as the concentrations of $\mathrm{CaCl}_{2}$ increased. The results indicated the role of endogenous TGase in cross-linking of proteins via the formation of $\varepsilon$-( $\gamma$-glutamyl) lysine linkages and protein-gellan conjugates. Similar results were observed for gumminess and chewiness. Both gumminess and chewiness of surimi gel increased noticeably when added with $\mathrm{GL}$ and $\mathrm{CaCl}_{2}$ in a dose dependent manner $(p<0.05)$. There were no differences in springiness ( $p>0.05$ ), except for gel containing $6 \%$ GL and $\mathrm{CaCl}_{2}\left(25-75 \mathrm{mmol} \mathrm{kg}{ }^{-1}\right)$, where the springiness was decreased when the concentrations of $\mathrm{CaCl}_{2}$ increased $(p<$ 0.05). Cohesiveness of surimi gels slightly decreased when GL was added. However, there was no difference in cohesiveness between surimi gel containing 2, 4 and $6 \%$ GL, regardless of $\mathrm{CaCl}_{2}$ levels $(p>0.05)$. Increasing $\mathrm{CaCl}_{2}$ concentration resulted in the decreases in cohesiveness of surimi gel containing $6 \% \mathrm{GL}$ $(p<0.05)$. This was in accordance with the lowed deformation (Fig. 1B). In the presence of cations, the gellan more likely becomes very rigid or brittle, associated with the loss in elasticity. ${ }^{36}$ In general, the addition of hydrocolloids into surimi, especially in the presence of cation, has been proposed to improve the textural properties of gel. ${ }^{37}$ The result suggested the filler or binder effect of GL via electrostatic interaction, which was triggered by calcium ion. Addition of GL could therefore play an essential role in textural properties of surimi gel from bigeye snapper.

3.1.3 Expressible moisture content. Expressible moisture content of gel from bigeye snapper surimi added with GL and $\mathrm{CaCl}_{2}$ at different levels is shown in Table 2. For surimi gel without $\mathrm{CaCl}_{2}$ addition, the expressible moisture content of surimi gel decreased when the levels of GL increased $(p<0.05)$, suggesting the increased water holding capacity. Decrease in expressible moisture content of gel containing $\mathrm{CaCl}_{2}$ was in agreement with the increase in breaking force (Fig. 1A). It has been known that the addition of divalent cation into surimi enhanced the cross-linking of proteins in the ordered fashion, resulting in the formation of stronger and fine network with greater water holding capacity of gels. ${ }^{38}$ The highest expressible moisture content was found in the control gel (without GL and $\left.\mathrm{CaCl}_{2}\right)(3.57 \%)(p<0.05)$.

Generally, the expressible moisture content is indicative for the water holding capacity of gel. ${ }^{39}$ Lower expressible moisture content of the gels suggests that more water was bound or retained in gel network. ${ }^{40}$ Normally, gums or hydrocolloids have been used in restructured products for improving the water holding capacity. ${ }^{37}$ The result suggested that GL could induce the formation of stronger network, in which more water could be held in the gel network. Moreover, GL might absorb water during the heating process via charged domains. Nevertheless, the increasing $\mathrm{CaCl}_{2}$ concentrations caused an increase in expressible moisture content of gels containing 2, 4 and 6\% GL ( $p<$ 0.05). This might be caused by the interaction between GL and myofibrillar proteins, especially in the presence of $\mathrm{CaCl}_{2} \mathrm{via} \mathrm{Ca}^{2+}$ bridges. As a consequence, more compact structure had less space for water entrapment. Additionally, free charged residues became less, resulting in the decreased number of sites for water binding. Therefore, GL and $\mathrm{CaCl}_{2}$ played an important role in water holding capacity of surimi gels from bigeye snapper.

3.1.4 Whiteness. Whiteness of gels from bigeye snapper surimi as affected by GL at different levels and $\mathrm{CaCl}_{2}$ at various concentrations is shown in Table 2. Surimi gel without GL had the lowest whiteness (78.35), compared with others $(p<0.05)$. Both GL and $\mathrm{CaCl}_{2}$ increased whiteness of surimi gels in a dose dependent manner $(p<0.05)$. In general, whiteness is used as 
Table 2 Expressible moisture content and whiteness of bigeye snapper surimi gel as affected by the addition of $\mathrm{GL}$ and $\mathrm{CaCl}_{2}$ at different levels ${ }^{b}$

\begin{tabular}{llll}
\hline $\begin{array}{l}\text { Gellan }^{a} \\
(\%)\end{array}$ & $\begin{array}{l}\mathrm{CaCl}_{2} \\
\left(\mathrm{mmol} \mathrm{kg}^{-1}\right)\end{array}$ & $\begin{array}{l}\text { Expressible moisture } \\
\text { content }(\%)\end{array}$ & Whiteness \\
\hline 0 & - & $3.57 \pm 0.15^{\mathrm{aA}}$ & $78.35 \pm 0.01^{\mathrm{bD}}$ \\
& 25 & $3.34 \pm 0.07^{\mathrm{bA}}$ & $78.44 \pm 0.04^{\mathrm{bD}}$ \\
& 50 & $3.21 \pm 0.18^{\mathrm{cA}}$ & $78.63 \pm 0.09^{\mathrm{abD}}$ \\
& 75 & $3.05 \pm 0.11^{\mathrm{dB}}$ & $78.77 \pm 0.05^{\mathrm{aD}}$ \\
& - & $2.15 \pm 0.12^{\mathrm{dB}}$ & $78.76 \pm 0.02^{\mathrm{cC}}$ \\
& 25 & $2.51 \pm 0.16^{\mathrm{cB}}$ & $78.86 \pm 0.14^{\mathrm{bcC}}$ \\
& 50 & $2.79 \pm 0.10^{\mathrm{bB}}$ & $79.49 \pm 0.08^{\mathrm{bC}}$ \\
& 75 & $3.73 \pm 0.23^{\mathrm{aA}}$ & $79.77 \pm 0.04^{\mathrm{aC}}$ \\
& - & $1.34 \pm 0.15^{\mathrm{dC}}$ & $78.90 \pm 0.03^{\mathrm{dB}}$ \\
& 25 & $1.92 \pm 0.08^{\mathrm{cC}}$ & $79.79 \pm 0.06^{\mathrm{cB}}$ \\
& 50 & $2.28 \pm 0.04^{\mathrm{bC}}$ & $80.97 \pm 0.01^{\mathrm{bB}}$ \\
& 75 & $2.53 \pm 0.07^{\mathrm{aC}}$ & $81.15 \pm 0.02^{\mathrm{aB}}$ \\
& - & $1.14 \pm 0.09^{\mathrm{dD}}$ & $79.40 \pm 0.05^{\mathrm{dA}}$ \\
& 25 & $1.44 \pm 0.08^{\mathrm{cD}}$ & $80.28 \pm 0.07^{\mathrm{cA}}$ \\
& 50 & $2.14 \pm 0.06^{\mathrm{bD}}$ & $81.39 \pm 0.03^{\mathrm{bA}}$ \\
& 75 & $2.35 \pm 0.08^{\mathrm{aD}}$ & $81.73 \pm 0.03^{\mathrm{aA}}$
\end{tabular}

${ }^{a}$ Based on surimi solid content. ${ }^{b}$ Values are presented as mean \pm SD $(n=3)$. Different lowercase superscripts in the same column within the same GL level indicate significant differences $(p<0.05)$. Different uppercase superscripts in the same column within the same $\mathrm{CaCl}_{2}$ indicate significant differences $(p<0.05)$.

one of the quality indices for surimi quality. ${ }^{41}$ The color characteristics of gels from fish muscle protein are largely dependent on the types and amounts of additives used. ${ }^{42}$ GL gel itself is opaque in appearance (data not shown). Light scattering effect of GL might contribute to the increased whiteness of surimi gels, especially when the higher level of GL was incorporated. Without GL addition, $\mathrm{CaCl}_{2}$ might form complex with some anion of muscle proteins. The formation of insoluble particles plausibly contributed to the light scattering in resulting gels. ${ }^{43}$ With the addition of GL, incorporation of $\mathrm{CaCl}_{2}$ at higher levels could increase whiteness of resulting gel. The same phenomenon was found in gelatin/gellan mixed system as reported by Lau et al. (2000). ${ }^{36}$ Gelatin gel became more dull/ opaque, particularly when $\mathrm{CaCl}_{2}$ was added. Furthermore, the increase in whiteness of surimi gel added with GL, especially in combination with $\mathrm{CaCl}_{2}$ at higher levels, was in accordance with the increased expressible moisture content. Free water or released water could cause light scattering or reflection on the surface of gel. This was associated with the increased whiteness. Thus, the use of GL in combination with $\mathrm{CaCl}_{2}$ is a potential approach for increasing gel strength and exhibited the positive effect on whiteness of resulting gel.

3.1.5 Protein patterns. Protein patterns of surimi gels without and with the addition of GL and $\mathrm{CaCl}_{2}$ at various levels are depicted in Fig. 2. Surimi paste contained myosin heavy chain (MHC) and actin as the major proteins, respectively. In the control gel (without GL and $\mathrm{CaCl}_{2}$ ), $\mathrm{MHC}$ band intensity was markedly decreased, compared to that of surimi paste. Crosslinking of proteins mediated by indigenous TGase played a major role in the disappearance of MHC band. ${ }^{31}$ For surimi gel without GL addition, the band intensity of MHC was decreased to higher extent when $\mathrm{CaCl}_{2}$ at higher levels was incorporated. Bigeye snapper surimi was reported to have the pronounced setting phenomenon. ${ }^{44}$ Nevertheless, degradation also occurred during gelation. When GL at all levels was added, no MHC band was observed. This result suggested that inter- and intramolecular cross-linking of MHC via non-disulfide covalent bonds still took place without interfering effect by GL. GL most likely interacted with muscle proteins by weak bonds, such as ionic bonds, hydrogen bonds and hydrophobic interactions, which could be destroyed by SDS used for solubilization. Therefore, the addition of GL had no effect on setting mediated by endogenous TGase, in which isopeptides could be formed. Formation of $\varepsilon$-( $\gamma$-glutamyl)lysine isopeptide is induced by TGase. ${ }^{45}$ When $\mathrm{CaCl}_{2}$ was incorporated, no MHC band was found in all gels, regardless of GL levels. It was noted that no changes in actin and tropomyosin band intensity were noticeable for all samples, irrespective of amounts of GL and $\mathrm{CaCl}_{2}$ used. Thus, actin was not served as the preferable substrate for TGase. ${ }^{46}$ In addition, actin was resistant to proteolysis. ${ }^{25}$ The result suggested that GL had no negative effect on surimi protein cross-linking, while $\mathrm{CaCl}_{2}$ could promote the polymerization of MHC.

\subsection{Sensory property of surimi gel as affected by gellan and $\mathrm{CaCl}_{2}$ at the selected concentration}

$\mathrm{CaCl}_{2}$ at higher concentrations yielded the gel with higher gel strength. $\mathrm{CaCl}_{2}$ at $75 \mathrm{mmol} \mathrm{kg}{ }^{-1}$ was selected to incorporate

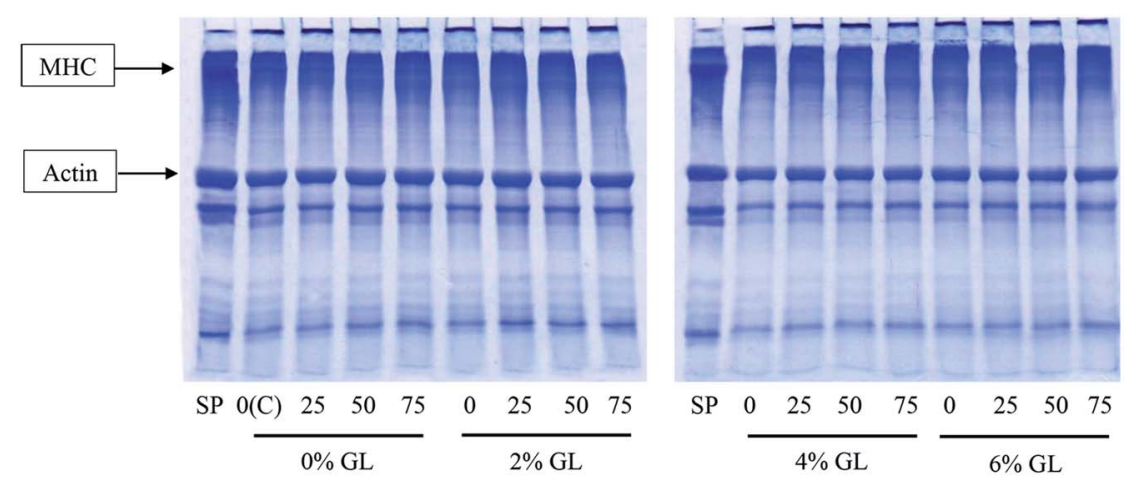

Fig. 2 Protein patterns of bigeye snapper surimi gel without and with $\mathrm{GL}$ and $\mathrm{CaCl}_{2}$ at different levels. MHC, myosin heavy chain; $\mathrm{SP}$, surimi paste; and $\mathrm{C}$, the control gel. Numbers $(0,25,50,75)$ denote the concentrations of $\mathrm{CaCl}_{2}\left(\mathrm{mmol} \mathrm{kg}^{-1}\right)$. 
into surimi gel containing GL at various levels. Addition of GL at higher levels increased the appearance likeness score of gel ( $p<$ 0.05) (Table 3). The presence of $\mathrm{CaCl}_{2}$ also caused the increase in appearance likeness score of gel, especially those containing GL at higher levels $(p<0.05)$. Surimi gel containing 6\% GL, incorporated with $\mathrm{CaCl}_{2}$, exhibited the highest appearance likeness score $(p<0.05)$. Regardless of $\mathrm{CaCl}_{2}$ added, the addition of GL increased firmness likeness score of resulting gel $(p<$ 0.05). When $\mathrm{CaCl}_{2}$ was incorporated, the firmness likeness score of gel containing 4\% GL was increased. Nevertheless, the decrease in firmness likeness score of gel containing 6\% GL was observed $(p<0.05)$. The incorporation of GL and $\mathrm{CaCl}_{2}$, especially at higher level, into surimi led to the rigid and brittle texture, which was not desirable for consumers. Petcharat and Benjakul (2017) also reported that fish gelatin gel containing GL at high level $(>5 \% \mathrm{GL})$ had the decrease in overall likeness score of resulting gel when $\mathrm{CaCl}_{2}$ was incorporated. ${ }^{17}$ Addition of GL and $\mathrm{CaCl}_{2}$ into surimi had no impact on springiness, color and odor likeness score of resulting gels $(p>0.05)$, except for gel added with $6 \%$ GL and $\mathrm{CaCl}_{2}$, which had the decreased springiness likeness score $(p<0.05)$. Taste likeness score of surimi gel was generally decreased as the levels of GL were increased $(p<0.05)$. At the same level of GL added, the decreased in taste likeness scores was found when $\mathrm{CaCl}_{2}$ was added $(p>0.05)$. High amount of $\mathrm{CaCl}_{2}$ could provide bitter and salty taste. ${ }^{47}$ As a result, slightly bitter and salty tastes might reduce taste likeness scores of resulting gel. The lower taste likeness score was found in surimi gel added with GL at higher levels. This probably due to the dilution effect of GL on myofibrillar proteins, especially when GL at higher proportion was present. Surimi contained several amino acids such as glutamic acid or aspartic acid, which are known to provide umami taste. ${ }^{48}$ For the gel containing GL (without $\mathrm{CaCl}_{2}$ ), surimi added with $6 \% \mathrm{GL}$ had the highest overall likeness score. When $\mathrm{CaCl}_{2}$ was incorporated, the highest overall likeness score was obtained for gel containing $4 \%$ GL $(p<0.05)$. This result suggested that $\mathrm{GL}$ at less amount $(4 \%)$ in combination with $\mathrm{CaCl}_{2}(75 \mathrm{mmol}$ $\mathrm{kg}^{-1}$ ) could improve property and acceptability of bigeye snapper surimi gel. Additionally, gel could maintain the deformability as indicated by the unchanged deformation (Fig. 1) and springiness (Table 3).

\subsection{Properties of surimi gel as affected by gellan and $\mathrm{CaCl}_{2}$ in the presence and absence of endogenous TGase}

3.3.1 Breaking force and deformation. Breaking force and deformation of surimi gels added with 4\% GL and $75 \mathrm{mmol}$ $\mathrm{CaCl}_{2} \mathrm{~kg}^{-1}$ in the presence and absence of endogenous TGase are shown in Table 4 . For both gels (with and without endogenous TGase), breaking force increased when GL or $\mathrm{CaCl}_{2}$ were added $(p<0.05)$. The results reconfirmed that the increase in breaking force of surimi gel was owing to electrostatic interaction between the carboxyl groups of GL and the positively charged domains of myofibrillar protein which could be enhanced by $\mathrm{Ca}^{2+}$ added. Thus, the addition of GL and $\mathrm{CaCl}_{2}$ could be used to reinforce surimi gel from bigeye snapper in the presence and absence of endogenous TGase. At the same level of GL and $\mathrm{CaCl}_{2}$ incorporated, gels containing TGase showed the higher breaking force than those without TGase $(p<0.05)$. Marked increase in breaking force was found in the presence of endogenous TGase, especially in gel containing 4\% GL and $75 \mathrm{mmol} \mathrm{CaCl}_{2} \mathrm{~kg}^{-1}(p<0.05)$, in which the increase in breaking force by $92.25 \%$ was achieved, compared with the control. Furthermore, the addition of GL and $\mathrm{CaCl}_{2}$ had no effect on deformation of surimi gels in the presence of TGase $(p>0.05)$ (Table 4). It was noted that the decrease in deformation was observed in surimi gel in the absence of TGase. $\mathrm{CaCl}_{2}$ addition had no effect on deformation, however GL (4\%) lowered the deformation of gel, regardless of $\mathrm{CaCl}_{2}$ addition. Thus, TGase played an essential role in deformation of surimi gel. In the present study, $\mathrm{NH}_{4} \mathrm{Cl}$ was used to suppress the formation of the $\varepsilon$ - $(\gamma$-glutamyl) lysine isopeptide via generated ammonia during the acyl transfer reaction between $\gamma$-carboxyamide groups of glutamine residues and primary amines and the excess amount of ammonium ion prevents further progress of the reaction. ${ }^{30}$ The decrease in deformation of surimi gel containing no TGase when GL was added was more likely due to the dilution effect of GL toward myofibrillar proteins in surimi. Therefore, both GL and $\mathrm{CaCl}_{2}$ were able to improve the textural property of surimi gels in the presence and absence of TGase.

3.3.2 Expressible moisture content. Expressible moisture content of gel from bigeye snapper surimi added with GL and $\mathrm{CaCl}_{2}$ in the presence and absence of TGase is shown in Table 4.

Table 3 Likeness score of bigeye snapper surimi gel as affected by the addition of $\mathrm{GL}$ and $\mathrm{CaCl}_{2}$ at different levels ${ }^{b}$

\begin{tabular}{|c|c|c|c|c|c|c|c|c|}
\hline $\begin{array}{l}\text { Gellan }^{a} \\
(\%)\end{array}$ & $\begin{array}{l}\mathrm{CaCl}_{2} \\
\left(\mathrm{mmol} \mathrm{kg}^{-1}\right)\end{array}$ & Appearance & Color & Odor & Firmness & Springiness & Taste & Overall \\
\hline \multirow[t]{2}{*}{0} & - & $8.11 \pm 1.08^{\mathrm{aC}}$ & $8.02 \pm 1.01^{\mathrm{aA}}$ & $7.39 \pm 1.53^{\mathrm{aA}}$ & $7.64 \pm 0.82^{\mathrm{aD}}$ & $7.53 \pm 1.51^{\mathrm{aA}}$ & $7.59 \pm 0.93^{\mathrm{aA}}$ & $7.68 \pm 0.62^{b D}$ \\
\hline & 75 & $8.09 \pm 1.40^{\mathrm{aC}}$ & $8.14 \pm 1.21^{\mathrm{aA}}$ & $7.20 \pm 2.20^{\mathrm{aA}}$ & $7.72 \pm 0.55^{\mathrm{aC}}$ & $7.51 \pm 1.12^{\mathrm{aA}}$ & $7.50 \pm 0.66^{\mathrm{bA}}$ & $7.81 \pm 0.71^{\mathrm{aC}}$ \\
\hline \multirow[t]{2}{*}{2} & - & $8.06 \pm 0.89^{\mathrm{aC}}$ & $8.16 \pm 1.06^{\mathrm{aA}}$ & $7.34 \pm 1.21^{\mathrm{aA}}$ & $7.80 \pm 0.56^{\mathrm{aC}}$ & $7.45 \pm 1.26^{\mathrm{aA}}$ & $7.58 \pm 0.42^{\mathrm{aA}}$ & $7.94 \pm 0.90^{\mathrm{bC}}$ \\
\hline & 75 & $8.13 \pm 0.65^{\mathrm{aC}}$ & $8.07 \pm 0.96^{\mathrm{aA}}$ & $7.28 \pm 1.47^{\mathrm{aA}}$ & $7.90 \pm 0.76^{\mathrm{aB}}$ & $7.52 \pm 1.08^{\mathrm{aA}}$ & $7.48 \pm 0.43^{\mathrm{bA}}$ & $8.32 \pm 0.86^{\mathrm{aB}}$ \\
\hline \multirow[t]{2}{*}{4} & - & $8.37 \pm 0.43^{\mathrm{bB}}$ & $8.09 \pm 0.49^{\mathrm{aA}}$ & $7.24 \pm 1.31^{\mathrm{aA}}$ & $7.98 \pm 0.59^{\mathrm{bB}}$ & $7.48 \pm 1.12^{\mathrm{aA}}$ & $7.60 \pm 0.77^{\mathrm{aA}}$ & $8.04 \pm 0.67^{\mathrm{bB}}$ \\
\hline & 75 & $8.45 \pm 0.32^{\mathrm{aB}}$ & $8.18 \pm 1.20^{\mathrm{aA}}$ & $7.22 \pm 1.66^{\mathrm{aA}}$ & $8.58 \pm 0.32^{\mathrm{aA}}$ & $7.50 \pm 1.15^{\mathrm{aA}}$ & $7.49 \pm 0.36^{\mathrm{bA}}$ & $8.71 \pm 0.43^{\mathrm{aA}}$ \\
\hline \multirow[t]{2}{*}{6} & - & $8.58 \pm 0.71^{\mathrm{bA}}$ & $8.11 \pm 0.96^{\mathrm{aA}}$ & $7.18 \pm 1.26^{\mathrm{aA}}$ & $8.60 \pm 0.78^{\mathrm{aA}}$ & $7.48 \pm 0.95^{\mathrm{aA}}$ & $7.38 \pm 0.86^{\mathrm{aB}}$ & $8.52 \pm 0.68^{\mathrm{aA}}$ \\
\hline & 75 & $8.64 \pm 0.63^{\mathrm{aA}}$ & $8.04 \pm 1.22^{\mathrm{aA}}$ & $7.21 \pm 1.47^{\mathrm{aA}}$ & $7.24 \pm 0.61^{b D}$ & $7.03 \pm 0.56^{\mathrm{bB}}$ & $7.27 \pm 0.90^{\mathrm{bB}}$ & $7.22 \pm 0.56^{\mathrm{bD}}$ \\
\hline
\end{tabular}

${ }^{a}$ Based on surimi solid content. ${ }^{b}$ Values are presented as mean \pm SD. Different lowercase superscripts in the same column within the same GL level indicate significant differences $(p<0.05)$. Different uppercase superscripts in the same column within the same $\mathrm{CaCl}_{2}$ indicate significant differences $(p<0.05)$. 
Table 4 Gel property of bigeye snapper surimi gel as affected by gellan and $\mathrm{CaCl}_{2}$ in the presence and absence of $\mathrm{TGase}{ }^{b}$

\begin{tabular}{|c|c|c|c|c|c|}
\hline Gellan $^{a}(\%)$ & $\mathrm{CaCl}_{2}\left(\mathrm{mmol} \mathrm{kg}^{-1}\right)$ & Breaking force $(\mathrm{g})$ & Deformation (mm) & $\begin{array}{l}\text { Expressible moisture } \\
\text { content }(\%)\end{array}$ & Whiteness \\
\hline \multicolumn{6}{|l|}{ With TGase } \\
\hline \multirow{3}{*}{4} & 75 & $438.67 \pm 10.01^{\mathrm{wAd}}$ & $10.49 \pm 0.12^{\mathrm{uAa}}$ & $3.05 \pm 0.18^{\mathrm{vBe}}$ & $78.74 \pm 0.05^{\mathrm{wAd}}$ \\
\hline & - & $484.37 \pm 6.55^{\mathrm{vAb}}$ & $10.47 \pm 0.17^{\mathrm{uAa}}$ & $1.35 \pm 0.17^{\mathrm{xBh}}$ & $78.91 \pm 0.01^{\mathrm{vAc}}$ \\
\hline & 75 & $609.96 \pm 11.36^{\mathrm{uAa}}$ & $10.38 \pm 0.17^{\mathrm{uAa}}$ & $2.59 \pm 0.13^{\mathrm{wBg}}$ & $81.14 \pm 0.03^{\mathrm{uAa}}$ \\
\hline \multirow[t]{2}{*}{0} & - & $182.99 \pm 19.52^{\mathrm{xBh}}$ & $6.18 \pm 0.23^{\mathrm{uBb}}$ & $4.48 \pm 0.30^{\mathrm{uAa}}$ & $77.44 \pm 0.10^{\mathrm{xBh}}$ \\
\hline & 75 & $242.96 \pm 12.13^{\mathrm{wBg}}$ & $6.23 \pm 0.61^{\mathrm{uBb}}$ & $4.11 \pm 0.17^{\mathrm{vAb}}$ & $77.72 \pm 0.05^{\mathrm{wBg}}$ \\
\hline \multirow[t]{2}{*}{4} & - & $369.23 \pm 8.11^{\mathrm{vBe}}$ & $5.33 \pm 0.31^{\mathrm{vBc}}$ & $2.77 \pm 0.23^{\mathrm{xAf}}$ & $78.40 \pm 0.10^{\mathrm{vBe}}$ \\
\hline & 75 & $473.27 \pm 14.83^{\mathrm{uBc}}$ & $5.34 \pm 0.47^{\mathrm{vBc}}$ & $3.72 \pm 0.19^{\mathrm{wAc}}$ & $80.68 \pm 0.02^{\mathrm{uBb}}$ \\
\hline
\end{tabular}

${ }^{a}$ Based on surimi solid content. ${ }^{b}$ Values are presented as mean \pm SD. Lowercase $(\mathrm{a}-\mathrm{h})$ superscripts in the same column indicate significant differences $(p<0.05)$. Lowercase $(\mathrm{u}-\mathrm{x})$ superscripts in the same column within the same TGase condition indicate significant differences $(p<$ 0.05). Uppercase (A and B) superscripts in the same column within the same $\mathrm{GL} / \mathrm{CaCl}_{2}$ indicates significant differences $(p<0.05)$.

Addition of GL with and without $\mathrm{CaCl}_{2}$ into surimi decreased expressible moisture content of the resulting gels, compared to the control $(p<0.05)$. The decreased expressible moisture content indicated that more favorable physical entrapment of water occurred in the protein matrix. In general, polysaccharides namely starch, carboxymethylcellulose, locust bean gum, xanthan gum, konjac glucomannan, curdlan and sodium alginate could be used to improve protein network and increase water holding capacity of protein gel. ${ }^{37}$ Ding et al. (2011) suggested that the addition of $\mathrm{CaCl}_{2}\left(10 \mathrm{mmol} \mathrm{kg}^{-1}\right)$ could improve water holding capacity of suwari and kamaboko gels from yellowcheek carp and grass carp surimi. ${ }^{22}$ The incorporation of GL and $\mathrm{CaCl}_{2}$ thus played an essential role in gel strengthening as evidenced by the highest breaking force of gel containing $4 \% \mathrm{GL}$ and $75 \mathrm{mmol} \mathrm{CaCl}_{2} \mathrm{~kg}^{-1}$. However, the expressible moisture content of gel containing 4\% GL was lower than that of gel incorporated with both $4 \% \mathrm{GL}$ and $75 \mathrm{mmol} \mathrm{CaCl}_{2} \mathrm{~kg}^{-1}$. More compact structure, having less space for water entrapment, presumably contributed to the lower water holding capacity of gel added with both GL and $\mathrm{CaCl}_{2}$. It was noted that all samples containing TGase showed higher water holding capacity than those without TGase $(p<0.05)$ as indicated by the higher expressible moisture content of the latter. These results revealed that higher endogenous TGase was required for development of myofibrillar protein network in conjunction with GL addition, which could hold or entrap water in the gel.

3.3.3 Whiteness. Whiteness of gels from bigeye snapper surimi in the presence and absence of TGase as affected by GL and $\mathrm{CaCl}_{2}$ is shown in Table 4 . The increases in whiteness were found in surimi gels added with both $\mathrm{GL}$ and $\mathrm{CaCl}_{2}$, irrespective of endogenous TGase $(p<0.05)$. The increase in whiteness of surimi gels containing both GL and $\mathrm{CaCl}_{2}$ was more likely due to light scattering effect of gellan and released water. Hydrocolloids generally have no significant effect on color of restructured products. ${ }^{22}$ Nevertheless, Hu et al. (2015) found that the addition of curdlan at levels lower than $4 \%$ paste could increase the whiteness of hairtail surimi. ${ }^{49}$ Moreover, Zhang et al. (2015) reported that the addition of deacetylated konjac glucomannan into Alaska pollock surimi, subjected to a high temperature $\left(120^{\circ} \mathrm{C}\right)$ treatment, increased the whiteness of surimi gels. ${ }^{50}$ When both GL and $\mathrm{CaCl}_{2}$ were added, surimi gels had higher whiteness than those containing GL or $\mathrm{CaCl}_{2}$ alone $(p<0.05)$. Benjakul et al. (2010) found that the addition of whey protein concentrate in combination with $\mathrm{CaCl}_{2}\left(50 \mathrm{mmol} \mathrm{kg}{ }^{-1}\right)$ into surimi from goatfish (Mulloidichthys martinicus) resulted in the increased whiteness of both kamaboko and modori gels. ${ }^{51}$ In the presence of TGase, the addition of both GL and $\mathrm{CaCl}_{2}$ increased whiteness of gels more slightly than those without TGase $(p<0.05)$. Cross-links mediated by TGase was another factor governing the whiteness of surimi gel, regardless of additive used. Thus, the use of GL in combination with $\mathrm{CaCl}_{2}$ had the positive effect on whiteness of resulting gel, especially in the presence of TGase.

3.3.4 Dynamic rheology. Viscoelasticity determines quality of surimi products and the ingredients used in their preparation are significant factors influencing the rheological properties of surimi. ${ }^{52}$ Elastic modulus $\left(G^{\prime}\right)$ is a good index for heat induced gel formation of food proteins. ${ }^{53}$ Changes in $G^{\prime}$ of bigeye snapper surimi paste added with GL and $\mathrm{CaCl}_{2}$ alone or in combination in the presence and absence of endogenous TGase during transition from sol to gel as a function of temperature are depicted in Fig. 3A. Similar $G^{\prime}$ curves were observed for all surimi pastes in the presence of TGase. Gel samples added with GL or $\mathrm{CaCl}_{2}$ or both showed the higher $G^{\prime}$ than the control (without GL and $\mathrm{CaCl}_{2}$ ). The highest $G^{\prime}$ was observed in surimi paste containing $4 \%$ GL in combination with $\mathrm{CaCl}_{2}$ at $75 \mathrm{mmol} \mathrm{kg}{ }^{-1}$. These results were in accordance with the highest breaking force of gel added with both $4 \%$ GL and $75 \mathrm{mmol} \mathrm{CaCl}_{2} \mathrm{~kg}^{-1}$ (Table 4). In the presence of TGase, $G^{\prime}$ of control gel increased continuously and reached the highest value at approximately $35{ }^{\circ} \mathrm{C}$. This indicated the formation of protein network via weak bonds, e.g. hydrogen bonds between protein molecules. ${ }^{54}$ Thereafter, $G^{\prime}$ rapidly decreased and the lowest value was obtained at about $50{ }^{\circ} \mathrm{C}$. Degradation mediated by endogenous proteolytic enzymes in the temperature range of 50-60 ${ }^{\circ} \mathrm{C}$ (ref. 25) and disaggregation of actin-myosin network 
$\mathbf{A}$

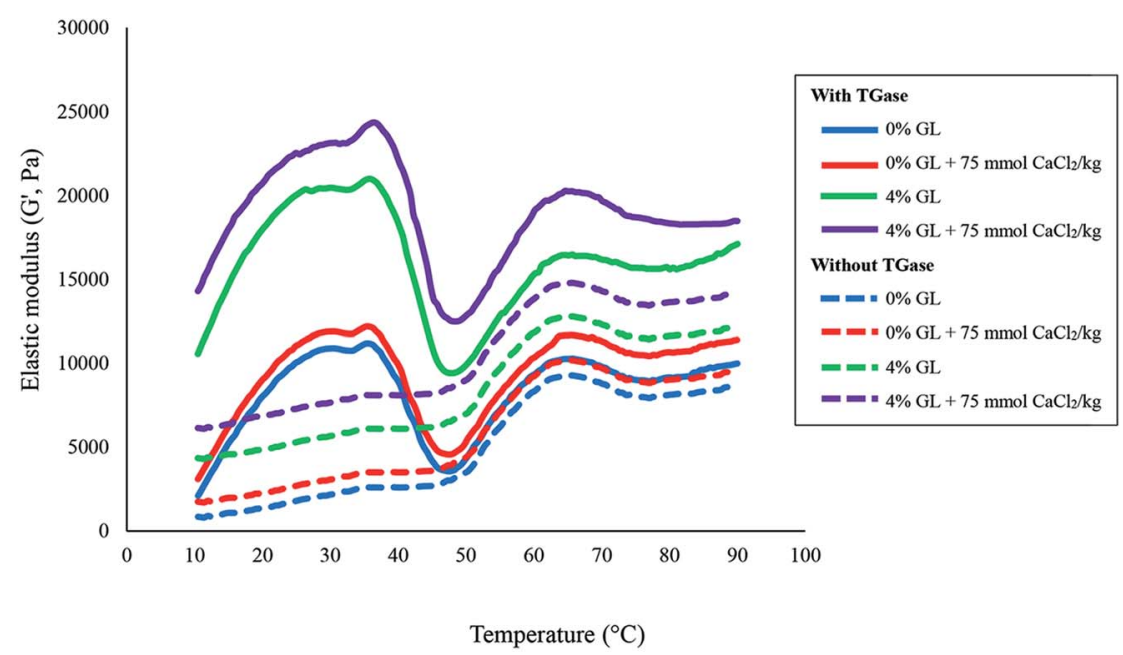

B

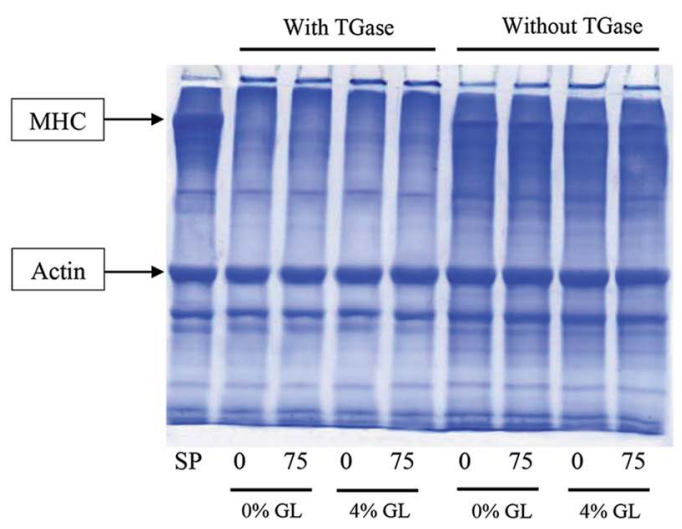

Fig. 3 Elastic modulus $\left(G^{\prime}\right)$ during heating of bigeye snapper surimi paste $(A)$ and protein patterns (B) of bigeye snapper surimi gel without and with $\mathrm{GL}$ and $\mathrm{CaCl}_{2}$ at different levels in the presence and absence of TGase. MHC, myosin heavy chain; SP, surimi paste. Numbers $(0,75)$ denote the concentrations of $\mathrm{CaCl}_{2}\left(\mathrm{mmol} \mathrm{kg}^{-1}\right)$.

structure more likely enhanced mobility of proteins, resulting in a decreased $G^{\prime} .^{50} G^{\prime}$ was subsequently increased again when heated up to $65{ }^{\circ} \mathrm{C}$. This probably resulted from an increase in the number of cross-links between dissociated protein molecules and the further denaturation of MHC and actomyosin, leading to a formation of a thermo-irreversible gel network. ${ }^{55}$ Unfolded proteins might undergo the aggregation via reactive groups or domains. Hydrophobic domains plausibly interacted each other via hydrophobic-hydrophobic interaction, while sulfhydryl groups were oxidized, in which disulfide bond could be formed. ${ }^{25}$ Thereafter, $G^{\prime}$ slightly decreased until the temperature reached $80{ }^{\circ} \mathrm{C}$. Weak bonds such as hydrogen bonds might be destroyed during heating at high temperature. Slight increase in $G^{\prime}$ was found after further heating up to $90{ }^{\circ} \mathrm{C}$, suggesting the continuous aggregation of unfold proteins as induced by high temperature.

$G^{\prime}$ curves of surimi pastes in the absence of TGase were different from those observed for pastes with TGase. Within the temperature range of $10-50{ }^{\circ} \mathrm{C}, G^{\prime}$ continuously increased and reached the constant value at approximately $35-45^{\circ} \mathrm{C}$. No sharp decrease in $G^{\prime}$ was found at the aforementioned temperature range. It was assumed that constant increase in $G^{\prime}$ in the range of $10-50{ }^{\circ} \mathrm{C}$ was associated with the gradual interaction of muscle proteins in the absence of TGase, in which no crosslinking mediated by non-disulfide covalent bonds was involved. As a consequence, no drastic increase in $G^{\prime}$ was found within the temperature range of $10-35{ }^{\circ} \mathrm{C}$. TGase was a potential protein cross-linking enzyme, which could introduce the strong bond to stabilize protein network. During 50$90{ }^{\circ} \mathrm{C}$, the similar trend was noticeable to those of paste samples containing TGase. At the same level of GL and $\mathrm{CaCl}_{2}$ added, $G^{\prime}$ of pastes in the presence of TGase was higher than that in the absence of TGase. Nevertheless, the addition of GL and $\mathrm{CaCl}_{2}$ alone or in combination also increased $G^{\prime}$ of surimi pastes in the absence of TGase when compared with the corresponding control. The highest $G^{\prime}$ was found in paste added with $4 \% \mathrm{GL}$ and $\mathrm{CaCl}_{2}$, followed by the paste containing $4 \% \mathrm{GL}$ and paste added with $\mathrm{CaCl}_{2}$, respectively. The result reconfirmed that GL acted as an active filler, which could increase the elastic modulus via ionic interaction. Furthermore, the addition of $\mathrm{CaCl}_{2}$ could link the network structure in the gel matrix via salt bridge. 
3.3.5 Protein patterns. Protein patterns of surimi gels without and with the addition of GL and $\mathrm{CaCl}_{2}$ alone or in combination in the presence and absence of TGase are shown in Fig. 3B. MHC and actin were found as the major proteins in surimi paste. In the presence of TGase, MHC of control gels completely disappeared. The disappearance of MHC band was mostly mediated by endogenous TGase. ${ }^{25}$ When GL and/or
$\mathrm{CaCl}_{2}$ were added, no differences in protein patterns were observed. This result reconfirmed that both GL and $\mathrm{CaCl}_{2}$ had no effect on inter- and intra-molecular cross-linking of MHC via non-disulfide covalent bonds mediated by endogenous TGase. Surimi used in the presence study might contain the sufficient indigenous $\mathrm{Ca}^{2+}$, which was enough for activation of TGase. In the absence of TGase, MHC was more retained when compared

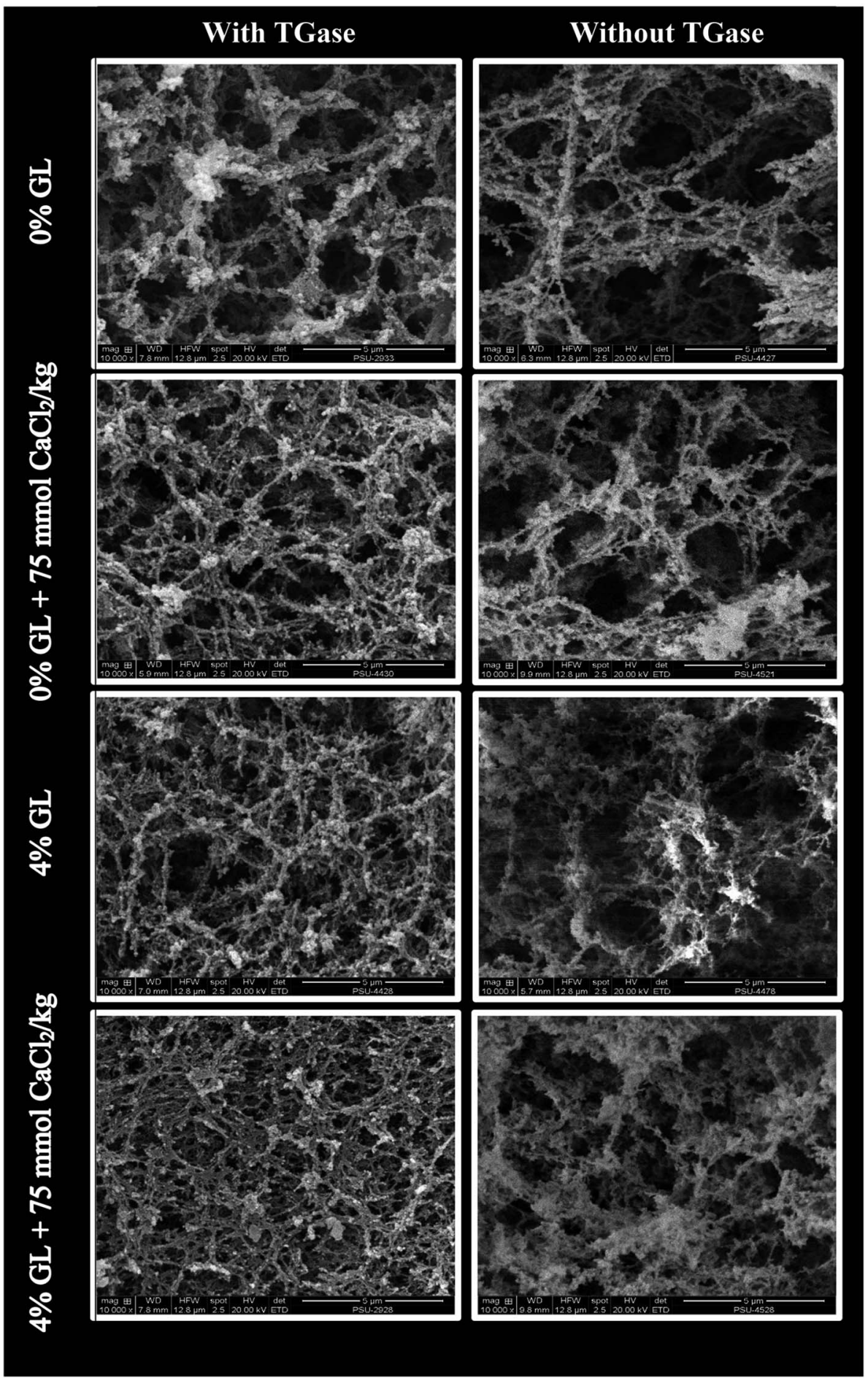

Fig. 4 Electron microscopic images of surimi gel as affected by the addition of $\mathrm{GL}$ and $\mathrm{CaCl}_{2}$ in the presence and absence of TGase. Magnification: $10000 \times$ 
with that found in surimi gel containing TGase. Nevertheless, no difference in MHC band intensity of gel as affected by GL and/or $\mathrm{CaCl}_{2}$ incorporated was observed. The result reflected the role of endogenous TGase in cross-linking of myofibrillar proteins, particularly MHC during setting of surimi. The addition of $\mathrm{NH}_{4} \mathrm{Cl}$ could inhibit TGase reaction in surimi. Moreover, actin and tropomyosin band density in all samples remained unchanged, regardless of TGase. It could be inferred that GL and $\mathrm{CaCl}_{2}$ at the level tested had no effect on polymerization of myosin heavy chain both in the presence and absence of TGase.

3.3.6 Microstructures. Microstructure of the selected surimi gels from bigeye snapper including (1) control gel (without GL and $\mathrm{CaCl}_{2}$ ), (2) gel added with $75 \mathrm{mmol} \mathrm{CaCl} \mathrm{kg}^{-1}$, (3) gel added with $4 \%$ GL and (4) gel added with $4 \%$ GL in combination with $75 \mathrm{mmol} \mathrm{CaCl}_{2} \mathrm{~kg}^{-1}$ in the presence and absence of TGase were visualized by SEM as shown in Fig. 4. In the absence of TGase, a coarser network with the larger void or cavities was found in the control gel (without GL or $\mathrm{CaCl}_{2}$ addition). This was in accordance with the lowest breaking force and water holding capacity (Table 4). Finer and denser structure was observed in gel added with GL or $\mathrm{CaCl}_{2}$. Nevertheless, the highest compactness with the highest interconnectivity of proteins was observed in gel containing both $4 \%$ GL and $75 \mathrm{mmol} \mathrm{CaCl}_{2} \mathrm{~kg}^{-1}$. These observations suggested that GL might distribute uniformly as the active filler in the ordered network and was able to interact with myofibrillar proteins of surimi via ionic interaction. The results also confirmed the presumption that $\mathrm{Ca}^{2+}$ could promote interconnection of protein-protein and protein-gellan via salt bridge. The control gels in the absence of TGase showed more discontinuous network with larger grooves and holes, compared with the control gel containing TGase. Similar trend of microstructure was also found in surimi gel without TGase. Nevertheless, surimi gels in the presence of TGase had finer and denser structure than those without TGase when both GL and $\mathrm{CaCl}_{2}$ was added. This indicated the essential role of endogenous TGase in gel strengthening of surimi. Therefore, GL and $\mathrm{CaCl}_{2}$ at appropriate levels could strengthen gel network of surimi in the presence and absence of TGase as evidenced by finer and more ordered network with increased compactness.

\section{Conclusions}

Gel properties of surimi from bigeye snapper were governed by level of GL and $\mathrm{CaCl}_{2}$. The addition of GL and $\mathrm{CaCl}_{2}$ increased breaking force, hardness and whiteness of surimi gel in a dose dependent manner. Water holding capacity of resulting gels increased when GL and $\mathrm{CaCl}_{2}$ were added. GL and $\mathrm{CaCl}_{2}$ at all levels had no effect on polymerization of MHC. Overall likeness score of resulting gels was increased as the level of GL was increased up to $4 \%$, especially in the presence of $75 \mathrm{mmol} \mathrm{CaCl}_{2} \mathrm{~kg}^{-1}$. In general, gels with TGase exhibited the higher gel strength and water holding capacity than those without TGase. Both GL and $\mathrm{CaCl}_{2}$ could improve gel property, namely breaking force, water holding capacity and whiteness of surimi gels without TGase. The addition of both GL and $\mathrm{CaCl}_{2}$ could enhance viscoelastic property of surimi paste during heating as indicated by the increased $G^{\prime}$. Finer and denser network was observed in surimi gel containing both GL and $\mathrm{CaCl}_{2}$ in the presence of TGase, compared to those without TGase. Therefore, GL at $4 \%$ in combination with $75 \mathrm{mmol} \mathrm{CaCl}_{2} \mathrm{~kg}^{-1}$ could improve gel strength of bigeye snapper surimi with low or high setting phenomenon regulated by endogenous TGase.

\section{Conflicts of interest}

There are no conflicts to declare.

\section{Acknowledgements}

This research was supported by Prince of Songkla University. The Thailand Research Fund (TRF) Distinguished Research Professor Grant was also acknowledged for the financial support.

\section{References}

1 J. W. Park, Surimi and surimi seafood, Taylor and Francis/CRC Press, Boca Raton, FL, USA, 2005.

2 Z. E. Sikorski, Chemical and functional properties of food proteins, Technomic Publishing Company, Inc., Lancaster, USA, 2001.

3 F. Z. B. Seighalani, J. Bakar, N. Saari and A. Khoddami, Anim. Prod. Sci., 2017, 57, 993-1000.

4 X. D. Sun and R. A. Holley, Compr. Rev. Food Sci. Food Saf., 2011, 10, 33-51.

5 M. R. Fowler and J. W. Park, Food Chem., 2015, 176, 448-454.

6 B. Herranz, C. A. Tovar, A. J. Borderias and H. M. Moreno, Innovative Food Sci. Emerging Technol., 2013, 20, 24-33.

7 Y. Hu, Y. Shao, C. Wu, C. Yuan, G. Ishimura, W. Liu and S. Chen, Food Chem., 2018, 242, 330-337.

8 S. S. Shitole, A. K. Balange and S. S. Gangan, Int. Aquat. Res., 2014, 6, 55.

9 Y. Wei, T. Zhang, F. Yu, Y. Xue, Z. Li, Y. Wang and C. Xue, Int. J. Food Prop., 2017, DOI: 10.1080/10942912.2017.1306557.

10 S. Wu, Int. J. Biol. Macromol., 2016, 93, 1118-1120.

11 A. Hunt and J. W. Park, J. Food Qual., 2013, 36, 51-58.

12 A. M. Barrera, J. A. Ramírez, J. J. González-Cabriales and M. Vázquez, Food Hydrocolloids, 2002, 16, 441-447.

13 C. E. Iurciuc, A. Savin, C. Lungu, P. Martin and M. Popa, Cellul. Chem. Technol., 2016, 50, 1-13.

14 S. Banerjee and S. Bhattacharya, Crit. Rev. Food Sci. Nutr., 2012, 52, 334-346.

15 M. T. Nickerson, A. T. Paulson and F. R. Hallett, Food Res. Int., 2008, 41, 462-471.

16 K. K. T. Goh, D. R. Haisman and H. Singh, Food Hydrocolloids, 2006, 20, 176-183.

17 T. Petcharat and S. Benjakul, Food Biophys., 2017, 12, 339347.

18 K. W. Lin and H. Y. Huang, Meat Sci., 2003, 65, 749-755.

19 T. Petcharat and S. Benjakul, Food Hydrocolloids, 2017, Submitted. 
20 S. Chanarat, S. Benjakul and A. H. Kittikun, J. Sci. Food Agric., 2012, 92, 844-852.

21 E. R. Morris, K. Nishinari and M. Rinaudo, Food Hydrocolloids, 2012, 28, 373-411.

22 Y. Ding, Y. Liu, H. Yang, R. Liu, J. Rong, S. Zhao and S. Xiong, Eur. Food Res. Technol., 2011, 233, 569-576.

23 AOAC, Official methods of analysis of AOAC International, AOAC International, Gaithersburg, MD, USA, 2000.

24 S. Benjakul, W. Visessanguan and C. Srivilai, J. Food Qual., 2001, 24, 453-471.

25 N. Buamard and S. Benjakul, Food Hydrocolloids, 2015, 51, 146-155.

26 S. Benjakul, W. Visessanguan and C. Chantarasuwan, LWTFood Sci. Technol., 2004, 37, 177-185.

27 U. K. Laemmli, Nature, 1970, 227, 680-685.

28 H. W. Robinson and C. G. Hogden, J. Biol. Chem., 1940, 135, 707-725.

29 M. C. Meilgaard, B. T. Carr and G. V. Civille, Sensory evaluation techniques, CRC press, Florida, 2007.

30 S. Benjakul, W. Visessanguan and S. Pecharat, Food Chem., 2004, 85, 91-99.

31 A. Singh and S. Benjakul, J. Texture Stud., 2017, 1-9, DOI: 10.1111/jtxs.12262.

32 R. G. D. Steel and J. H. Torrie, Principles and procedures of statistics. A biometrical approach, McGraw-Hill, New York, 1980.

33 P. Montero, J. L. Hurtado and M. Pérez-Mateos, Food Hydrocolloids, 2000, 14, 455-461.

34 V. Evageliou, A. Gerolemou, A. Zikas, A. Basios and M. Komaitis, Int. J. Food Sci. Technol., 2011, 46, 1001-1006.

35 S.-H. Eom, J. Kim, B.-Y. Son, D. H. You, J. M. Han, J.-H. Oh, B.-Y. Kim and C.-S. Kong, Fish. Aquat. Sci., 2013, 16, 143-147.

36 M. H. Lau, J. Tang and A. T. Paulson, Food Res. Int., 2000, 33, 665-671.
37 J. A. Ramírez, R. M. Uresti, G. Velazquez and M. Vázquez, Hydrocolloids, 2011, 25, 1842-1852.

38 Y. Arfat and S. Benjakul, Food Biosci., 2013, 3, 1-9.

39 S. Rawdkuen, S. Benjakul, W. Visessanguan and T. C. Lanier, Hydrocolloids, 2004, 18, 259-270.

40 N. Hamzah, N. M. Sarbon and A. M. Amin, J. Food Sci. Technol., 2015, 52, 4773-4784.

41 K. Duangmal and A. Taluengphol, Int. J. Food Sci. Technol., 2010, 45, 48-55.

42 S. Rawdkuen, S. Benjakul, W. Visessanguan and T. C. Lanier, J. Food Process. Preserv., 2007, 31, 492-516.

43 S. Benjakul, W. Visessanguan and Y. Kwalumtharn, Int. J. Food Sci. Technol., 2004, 39, 773-781.

44 S. Benjakul and W. Visessanguan, Food Res. Int., 2003, 36, 253-266.

45 T. Yin and J. W. Park, Food Chem., 2014, 150, 463-468.

46 S. Rawdkuen and S. Benjakul, Food Chem., 2008, 106, 10771084.

47 H. T. Lawless, F. Rapacki, J. Horne and A. Hayes, Food Qual. Prefer., 2003, 14, 319-325.

48 E. N. Dewi, U. Amalia and M. Mel, Aquat. Procedia, 2016, 7, 59-65.

49 Y. Hu, W. Liu, C. Yuan, K. Morioka, S. Chen, D. Liu and X. Ye, Food Chem., 2015, 176, 115-122.

50 T. Zhang, Y. Xue, Z. Li, Y. Wang and C. Xue, Food Hydrocolloids, 2015, 43, 125-131.

51 S. Benjakul, S. Yarnpakdee, W. Visessanguan and S. Phatcharat, J. Texture Stud., 2010, 41, 341-357.

52 H. Chen and C. Xue, Trans. Chin. Soc. Agric. Mach., 2009, 40, 119-125.

53 B. N. Pietrowski, R. Tahergorabi and J. Jaczynski, Food Hydrocolloids, 2012, 27, 384-389.

54 N. Buamard, S. Benjakul and K. Konno, J. Texture Stud., 2017, 48, 47-56.

55 S. Mleko and E. A. Foegeding, J. Food Sci., 2000, 65, 139-143. 